\title{
Cultural vocabulary in teaching Turkish as a foreign language
}

\author{
Burak Tüfekçioğlu a * \\ a Türkçe ve Sosyal Bilimler Eğitimi Bölümü, Eskişehir Osmangazi Üniversitesi, Eskişehir, 26040, Türkiye
}

Received 7 August 2020 | Received in revised form 24 February 2021 | Accepted 3 April 2021

\author{
APA Citation: \\ Tüfekçioğlu, B. (2021). Cultural vocabulary in teaching Turkish as a foreign language. Eurasian Journal of Applied \\ Linguistics, 7(1), 338-358. \\ Doi: $10.32601 /$ ejal.911449
}

\begin{abstract}
This study aims at specifying cultural words in teaching Turkish as a foreign language according to their proficiency levels (A1/2, B1/2, and C1/2) and analyzing the difference between the proficiency levels of these cultural words in terms of their frequency. For this purpose, a cultural corpus of 112.350 tokens in total has been created based on written and oral cultural texts. In this cultural corpus, nouns and verbs in the first 2000 in terms of their frequency have been compared with nouns and verbs in the most common 2000 Turkish words, and nouns and verbs that are not in the most common 2000 Turkish words have been marked as cultural words. Then, the cultural words have been compared with the textbooks used in teaching Turkish as a foreign language. The proficiency levels of their English equivalents in Cambridge Learner's Dictionary and the context in which they are used in the corpus have been checked and listed according to their levels. Finally, the list has been edited according to the opinions of two experts teaching Turkish as a foreign language at university level. The differences in the frequency of cultural words according to their proficiency levels have been analyzed using Kruskal-Wallis and MannWhitney U tests. Findings show that there is a statistically significant difference between A1 and A2; A2 and $\mathrm{B} 1 ; \mathrm{B} 1$ and $\mathrm{B} 2 ; \mathrm{C} 1$ and $\mathrm{C} 2$ levels of the cultural words in terms of frequency, whereas there is no significant difference between cultural words at B2 and $\mathrm{C} 1$ levels in terms of frequency. In these findings, it has been seen that the most cultural words are at B1 level in terms of number and concept diversity, and it has been concluded that B1 level could be a threshold in the teaching of cultural words.
\end{abstract}

(C) 2021 EJAL \& the Authors. Published by Eurasian Journal of Applied Linguistics (EJAL). This is an open-access article distributed under the terms and conditions of the Creative Commons Attribution license (CC BY-NC-ND) (http://creativecommons.org/licenses/by-nc-nd/4.0/).

Keywords: Teaching Turkish as a foreign language; corpus linguistics; culture in foreign language teaching, vocabulary, vocabulary teaching

\section{Introduction}

\subsection{Culture and Teaching Vocabulary}

Culture consists of a wide range of concepts, from education to daily life, and from personal development of individuals to institutional formation of societies. In its

\footnotetext{
* Corresponding author. Tel.: +0-222 239 3750-1646

E-mail address: burak.tufekcioglu@ogu.edu.tr

http://dx.doi.org/10.32601/ejal.911449
} 
historical use, the concept of culture was associated with animal breeding, growing crops, and religious rituals, from which the word 'cult' was derived, however; from the 16 th century to the 19th century, the term was used to define learning in a broad sense and the development of individual human mind and personal manners (Smith \& Riley, 2016). Today, culture is the collective programming of the mind that distinguishes the members of one group or category of people from others and it is always a collective phenomenon, but it can be connected to different collectives (Hofstede, 2011).

Today, with the developments in the societal life, there are various definitions of culture; nearly a hundred definitions in literature (Haviland, Prins, Wairath \& McBride, 2008). The fact that there are so many definitions of culture as a concept may be the result of its association with different disciplines. In this context, language as a human-specific phenomenon, cannot be studied separately from culture, and cultural linguistics, which explicitly reveals the relationship between linguistics and cultural studies (Baydak, Scharioth \& Il'yashenko, 2015), studies the cultural codes created by the conceptualizations of experiences (Sharifian, 2017). Culture is an important variable that should be taken into account in many respects in language teaching. Culture affects the use of language learning strategies (Oxford, 1996). In language teaching, culture is handled in two basic approaches; modernist and postmodernist. In the modernist approach, the term culture associates with the context of the living and spoken language by native speakers, and is seen as more or less homogeneous with the institutions of national society, its traditions and daily life, while in the post-modernist approach, culture points to the concepts of discourse, identity and power, and individual mobility and entrepreneurship are taken into account (Kramsch, 2006). In this respect, it is clear that culture has an individual and social aspect. In foreign language teaching, social cultural elements are transferred to the learner through teachers and materials.

In terms of foreign language teaching, language and culture teaching takes place in all of the listening, reading, speaking and writing skills as a whole, and while the learner improves his language skills in a foreign language, he/she also learns the culture of the target language. In addition, covering cultural concepts in vocabulary teaching, an important component of language teaching, is important in terms of teaching the target culture. That is because the close connection between language and culture and the semantic level of the vocabulary of a language reflect the common culture of the speakers of that language (House, 2020). Besides, there is a positive relationship between vocabulary development and language achievement, and the development of vocabulary contributes to the language development of learners (Koizumi \& In'nami, 2013; Masrai \& Milton, 2018; Matthews, 2018; McLean, Stewart \& Batty, 2020; Staehr, 2008). Thus, improving the vocabulary of learners can be considered as one of the main goals of language teaching.

In vocabulary teaching, it is essential to specify the words to be taught according to proficiency levels (A1/2, B1/2, C1/2) both for learners and for teachers and material designers. Regarding this, vocabulary lists help learners, especially at the beginner 
level, about where to start and it also provides great convenience for teachers in preparing materials and textbooks (Brezina \& Gablasova, 2013). Word lists prepared based on frequency or context, designed for the purpose of instruction, constitute the first step in the design of vocabulary teaching material. Word lists can play a significant role in organizing vocabulary lists for language courses, guiding learners in their independent study, and informing course and material designers in selecting texts and developing learning activities (Coxhead, 2000). Moreover, teaching vocabulary activities through vocabulary lists are thought to help learners to develop their reading and writing skills (Khani \& Tazik, 2013; Vongpumivitch, Huang \& Chang, 2009). In addition, most vocabulary lists are used in establishing vocabulary learning goals, assessing vocabulary knowledge and growth, analyzing text difficulty and richness, creating and modifying reading materials, designing vocabulary learning tools, determining the vocabulary components of academic curricula, and fulfilling many other crucial academic needs (Gardner \& Davies, 2014). Looking at this information, the importance of vocabulary lists for both learners and teachers and material designers is obvious.

There are generally two principal approaches in establishing vocabulary lists; wordfamily approach (Coxhead, 2000; Kremmel, 2016; Yang, 2015) and pedagogical wordlist approach (Brezina \& Gablasova, 2013; Gardner \& Davies, 2014; Lei \& Liu, 2016). The term 'word family' is used to describe various words derived from the same root and the group of words they formed together (Aksan, 1971) and each family of words includes several independent word forms, root form it contains, inflections and derivations (Schmitt, 2008). The word-family approach is based on the principle that, in a broad sense, the collected words are separated according to their morphologically relevant associations. According to this principle, the meaning of word root is also related to other words derived from that word root, and this link can be perceived by learners.

Word-family approach is used because of some reasons; it can facilitate the understanding of the derived forms of a base word, there is some evidence suggesting that members of the same word family are stored together in the mental lexicon, and it facilitates specifying the words in the list as it includes all closely related affixed words to a word root or stem (Hyland \& Tse, 2007). However, the word list method is preferred to the word-family method for beginner level users whose morphological awareness and word derivation skills are limited, since there may be significant semantic differences between the words in the same word family, the type tags of the words in the same word family are not specified, and the ability to use word families depends on the morphology knowledge of the users, which is not always sufficient (Brezina \& Gablasova, 2013; Gardner \& Davies, 2014). Type tag information in wordlist approach is also important for Turkish language. For instance, words such as savaş (war) and boya (paint) can be used as a noun or a verb depending on the context. Moreover, there are homonyms such as the word çay (I) (tea), a hot drink, a word borrowed from Chinese and çay (II) (creek), a stream smaller than a river, of Turkish origin, and those features can be easily shown in the word list approach. 
Along with the need to consider many semantic and grammatical factors such as concept area, morphological and syntactic structure of the words in creating a pedagogical word list, the most prominent feature that determines the order of the words in the word lists is the frequency of the use of the word. In this respect, it is an important step to count the frequency of words while preparing a pedagogical word list. Additionally, learners can confuse words in alphabetical word lists, because words that are similar, but differ from each other in meaning are listed together in alphabetical lists (Coxhead, 2011). Looking at this information, a researcher prefers a word-family list or a pedagogical list, and an alphabetical list or a frequency list in terms of order, depending on their perspective.

\subsection{Cultural Vocabulary}

Understanding culture is not merely about knowing how language and culture intersect, but also knowing conventions and norms of interaction for participation in discourse communities (Michelson, 2018). It can be said that these tradition knowledge and norms of interaction become evident in cultural conceptualizations. Sharifian (2011) defines conceptualization as the social product of human cognition. Throughout history, societies have transferred their knowledge and experience to new generations. It becomes possible to conceptualize the values, beliefs and traditions of societies in minds and transfer these concepts to new generations through language. Cultural concepts were formed as a result of the conceptualizations in this transfer process. The cultural concept fulfills functions such as the storing, accumulating, transferring, and comprehending cultural knowledge and is the smallest unit of the cultural consciousness of societies, reflecting the internal characteristics of a phenomenon or object (Alimjanova, 2016). The concept is formed in the form of a word and concept-words can describe the material and spiritual cultural phenomena of the people and reflect the world view of that people in the language (Sergeyeva, 2014). However, the close relationship between language and culture is not limited to cultural concepts. In this regard, one of the essential purposes of language-teaching methodology is to determine the nature of cultural representations in the language system (Mikhaleva \& Régnier, 2014). However, while some words reflect cultural concepts that represent the values, beliefs and practices of the society they belong to, some words differ from their frequency of use in everyday language during the creation of cultural texts (such as introductions or statements in cultural rituals). For instance, while the word oklava (rolling pin) is not included in the most frequently used 2000 words in Turkish according to A Frequency Dictionary of Turkish (Aksan, Aksan, Mersinli \& Demirhan, 2017) based on the Turkish National Corpus, it ranks $94^{\text {th }}$ in terms of frequency in the created cultural corpus. Likewise, while the word bulgur (cracked wheat) is not among the first 2000 words, it ranks $89^{\text {th }}$ in the cultural corpus. In the scope of the study, cultural words have been included in the first 2000 words in the cultural corpus created, however, according to the Turkish National Corpus, they are accepted as nouns and verbs that are not included in the first 2000 words in current Turkish. Accordingly, in this study, "cultural words" are the words in 
the first 2000 in terms of frequency but not in the first 2000 according to A Frequency Dictionary of Turkish.

The purpose of the study is to specify the cultural words introducing Turkish culture in teaching Turkish as a foreign language according to their proficiency levels (A1/2, B1/2, and $\mathrm{C} 1 / 2)$ and to investigate the differences of these words according to their levels. In line with this purpose, it is aimed to make inferences about which cultural concepts should be included at which proficiency level in teaching Turkish as a foreign language. The study is important in teaching Turkish as a foreign language in terms of specifying the cultural words to be taught according to proficiency levels, designing reading and listening materials by using these specified cultural words, and specifying the cultural concepts that the learners should know according to their levels.

\subsection{Research questions}

The question 'What are the classified cultural words that introduce the Turkish culture in terms of teaching Turkish as a foreign language?' constitutes the issue of the study.

Depending on this basic problem, the researcher has tried to answer the following questions:

1. What are the nouns and the verbs that are considered as cultural words?

2. What are the levels of cultural words in teaching Turkish as a foreign language (A1, $\mathrm{A} 2, \mathrm{~B} 1, \mathrm{~B} 2, \mathrm{C} 1, \mathrm{C} 2)$ ?

3. Do cultural words differ according to the levels (A1, A2, B1, B2, C1, C2) in teaching Turkish as a foreign language?

\section{Method}

\subsection{The Corpus and Collection of Data}

A corpus is defined as a collection of pieces of language texts in electronic form for linguistic purposes, selected according to external criteria specified for representation, and using a language or language variety as a source of data as much as possible (Sinclair, 2005), and unlike large text archives, the language sections of large text collections kept in a digital environment that are marked in a specific frame in terms of phonetics, syntax and semantics (Tahiroğlu, 2008). The process of collecting, organizing and classifying language data according to the subject of the research is in the research field of corpus linguistics. While a corpus provides a qualitative and quantitative sampling of the data according to the frequency and coherence, in general, in corpus based studies, corpora data is generally used to investigate a theory or a hypothesis, and in this regard, corpus is accepted as a method in research (McEnery \& Hardie, 2012). Considering the corpora data, there are researches whose subject is directly language (Aksan, et al., 2017; Dang \& Webb, 2014; Göz, 2003; 
Ölker, 2011; Özkan, 2012) and researches in which the obtained data are used for educational purposes (Klimova, 2014; Lozano \& Mendikoetxea, 2013; Stoykova, 2014).

In this research, to gather the appropriate data for research purposes, a web corpus of 102.323 token is created using written texts as recipes, city guides, tourist attraction guides, biographies, festivals and festive tradition texts on the website Turkish Culture Portal (kulturportali, 2020) affiliated to Republic of Turkey Ministry of Culture and Tourism. In addition, a verbal collection of 10.027 token was created by transcribing YouTube videos on food service culture, music history, traditional Turkish handicrafts, historical place introductions, cultural rituals on the topics of history, city introductions, librarianship, local cuisine on the same website. The created corpus of 112.350 token serve as a web corpus and web as corpus enables the researcher to select and prepare the appropriate volume of data for various purposes (McEnery \& Hardie, 2012). The website, from which the corpus has been created, "was built in 2015 and provides written texts by experts of their fields, as well as many articles, e-books, photographs and videos in the sections of archaeology and history, language and literature, traditional cuisine, sights, folk culture, cultural heritage, art, souvenirs, touristic activities, Turkey in UNESCO, museums, geographically marked products and Turkish decorative arts" (kulturportali, 2021). In the selection of cultural words, the frequency of use was determined as a criterion and according to the corpus, the nouns and verbs that are in the first 2000 in terms of frequency have been included in the scope of the study. Then, the first 2000 words in the cultural corpus were compared with the first 2000 words in A Frequency Dictionary of Turkish. A Frequency Dictionary of Turkish is based on the National Turkish Corpus consisting of 50.997.016 token, covering a 23-year period between 1990-2013, and 98\% written and $2 \%$ verbal data (Aksan et al., 2017). As a result of this comparison, the words in the first 2000 in Turkish according to the A Frequency Dictionary of Turkish were evaluated as general words and excluded from the scope. 512 tokens, which were included in the first 2000 in the corpus but not in the first 2000 in A Frequency Dictionary of Turkish, were accepted as cultural words and included in the scope of the study.

\subsection{Data Analysis}

Within the scope of this research, the corpus texts have been acquired from Turkish Culture Portal website and the transcribed YouTube videos and these texts have been converted into 'Text Documents'. 112.350 tokens recorded as Text Documents are listed with the program "kfNgram" in terms of their frequency of use. As a result of this listing, it has been seen that 112.350 tokens in the cultural corpus consist of 10.386 individual words. Afterwards, nouns and verbs in the 10.386 individual words have been compared with the nouns and verbs in the first 2000 words in A Frequency Dictionary of Turkish and a list of cultural words has been compiled.

In the second step of the study, the list of words obtained has been ranked according to the levels of A1, A2, B1, B2, C1 and C2 in terms of teaching Turkish as a 
foreign language. For that purpose texbooks were used. "Textbooks powerful vehicles through which language learners are introduced to the target language communities and cultures" (Uzum, Yazan, Zahrawi, Bouamer \& Malakaj, 2021). To determine the proficiency level of words, 512 cultural word in the scope of the study have been compared with the vocabulary in the A1/2, B1/2 and C1 level textbooks, Istanbul Turkish for Foreigners and Gazi Turkish for Foreigners, used in Turkish Language Teaching courses in preparatory year of universities. Since these textbooks do not have a C2 level, a comparison could not be made at this level. Istanbul Turkish for Foreigners was prepared by experts of the field at Istanbul University, and Gazi Turkish for Foreigners was prepared by experts of the field at Gazi University. These books are used as textbooks in preparatory year to teach Turkish for general communication purposes to students who will study at undergraduate and graduate levels at universities. As a result of the comparison, the proficiency levels of the words in the cultural word list have been determined according to the level at which they are used in textbooks of teaching Turkish as a foreign language. Another result of the comparison is that 311 of 512 words are used in these textbooks. Proficiency levels of the remaining 201 words have been determined by considering the context in which they are used and their English equivalents in Cambridge Learner's Dictionary. In the next step, opinions of two field experts have been consulted about the compatibility of the cultural words whose levels have been specified as A1, A2, B1, B2, C1 and C2. One of the experts has taught Turkish as a foreign language at a university in Turkey for eight years and continues his $\mathrm{PhD}$ studies. The other expert has taught Turkish as a foreign language at another university in Turkey and has received a $\mathrm{PhD}$. In addition, these field experts do not know each other and did not communicate before and during their evaluation. Opinions of the experts on the proficiency levels of cultural words are shown in Table 1.

Table 1. Table of descriptive statistics on cultural words within the scope of the research

\begin{tabular}{llccc}
\hline & & \multicolumn{2}{c}{ Expert 2 } & Total \\
\cline { 3 - 4 } Expert 1 & Compatible & Not compatible & 497 \\
& Compatible & 482 & 15 & 15 \\
Total & Not compatible & 15 & 0 & 512 \\
\hline
\end{tabular}

When the expert opinions shown in Table 1 are examined, it is seen that both experts agree that the 482 words are compatible with their proficiency levels. However, there has been no consensus on the remaining 30 words. While the first expert states that 15 of these words are compatible with their levels, the second expert states that they are not. And, for the other 15 words, the first expert states that they are not compatible with their levels, whereas the second expert states that they are. When the expert opinions were studied in detail, it was seen that this disagreement was focused on city names and they have been levelled according to their familiarity (such as historical importance and being the capital) and population density. The differences in the frequencies of cultural words according to proficiency levels have been analyzed using Kruskal Wallis and Mann-Whitney U tests according to the results of the normality test of the data $(p=.00<p=.05)$. 


\section{Results}

\subsection{Cultural Words by Proficiency Levels}

\subsubsection{A1 Level Cultural Word List}

There are 100 words in total in A1 level cultural words list. Among these words, the most frequently used word is Türk (Turkish) with 405 repetitions. In terms of frequency, this word is followed by su bardağı (water glass) (226), çorba (soup) (219), eski (old) (147), mimar (architect) (141). The A1 level words in the word list prepared within the scope of the study include food words such as çorba (soup), soğan (onion); food-related objects such as su bardağı (water glass), yemek kaşığı (tablespoon), tencere (pot); objects related to daily life such as halı (carpet), kitap (book), and boya (paint). Animal words such as tavuk (chicken), yllan (snake) stand out in the A1 level word list. Ankara and Istanbul are included in the list as city names. The list includes country names such as Türkiye (Turkey), Çin (China); nationality names such as Türk (Turkish), Fransız (French); language names such as Türkçe (Turkish) and Arapça (Arabic). In the A1 level words list adjectives such as eski (old), kuru (dry), sicak (hot) and the verb dua et- (to pray) are included. Personal names like Mehmet, Ahmet, Ali are also included in the A1 level word list. In the group of personal names, Mustafa Kemal Atatürk, the founder of Turkish Republic, is repeated 106 times as Atatürk and 12 times as Mustafa Kemal. Regarding religious words, the word Allah (God) is used 15 times along with the verb dua et- (to pray) in the A1 level word list. (For the complete list of words, see Appendix 1).

\subsubsection{A2 Level Cultural Word List}

There are 111 words in total in A2 level and among these words, the most frequently used word is Osmanlı (Ottoman) with 178 repetitions. In terms of frequency, the word Osmanl is followed by Anadolu (Anatolia) (167), yağ (oil) (159), kültür (culture) (142), servis et- (to serve) (128). In the A2 level cultural word list, there are food words such as yağ (oil), hamur (dough). In addition, there are food related words such as menü (menu), cevizli (with walnuts), sebzeli (with vegetables), lezzet (taste), bulgurlu (with cracked wheat). In the A2 level cultural word list, there are object names such as çeşme (fountain), tava (pan), bez (cloth), kase (bowl) and tabak (plate). As geographical names, there are Anadolu (Anatolia), Avrupa (Europe), Ege (Aegean), Karadeniz (Black Sea). Moreover, the words Hiristiyan (Christian), Müslüman (Muslim) and İslam (Islam) are included as religious words. Adjectives in this list are geleneksel (traditional), yaklaşık (approximate). In the A2 level cultural word list, there are verbs like servis et- (to serve), ekle- (to add), sahip ol-. (For the complete list of words, see Appendix 2).

\subsubsection{B1 Level Cultural Word List}

There are 121 words in total in B1 level and among these words, the most frequently used word is antik (ancient) with 72 repetitions. In terms of frequency, the word antik is followed by şelale (waterfall) (70), Edirne (a city in Turkey) (57), kule 
(tower) (56), and eşsiz (unique) (52). As of B1 level, it is seen that cultural words have diversified and their frequency has decreased to a certain extent. There are geographical names such as şelale (waterfall) and vadi (valley) and words related to a religion or belief such as bereket (abundance), dini (religious) at B1 level. In the list of B1 level cultural words, the words antik (ancient), kurtuluş savaşı (liberation war), are words related to history. In the list, there are the words dana (calf), manda (buffalo) in the animal theme. Adjectives in this list are eşsiz (unique), doğal (natural), yazllı (written), muhteşem (magnificent). In the B1 level cultural word list, there are verbs like islat- (to wet), bulun- (to attend), gezdir- (to walk around). (For the complete list of words, see Appendix 3).

\subsubsection{B2 Level Cultural Word List}

There are 92 tokens in total in B2 level and among these words, the most frequently used word is pişiril- (to be cooked) with 108 repetitions. In terms of frequency, the word pişiril- is followed by karıştırıl- (to be mixed) (85), karagözhacivat (a shadow play) (84), kazı (excavation) (75), and Roma dönemi (Roman period) (68). In the B2 level cultural word list, it is seen that there are historical concepts and names such as karagöz-hacivat (a shadow play) and kazı (excavation). In the B2 level word list, religious place names and concepts such as yağmur duası (rain prayer), türbe (tomb) and iftar (iftar) are also included. Food words at the B2 level consist of the words misir unu (corn flour), kemik suyu (broth), bakla (horse bean). The words tabiat parkı (nature park), Selimiye Camii (Selimiye Mosque) and Sümela Manastırı (Sümela Monaster) in the list also refer to historical places and buildings. Adjectives in this list are kültürel (cultural), toplumsal (social) and ticari (commercial). In the B1 level cultural word list, there are verbs like pişiril (to be cooked) and içer- (to include). (For the complete list of words, see Appendix 4).

\subsubsection{C1 Level Cultural Word List}

There are 55 words in $\mathrm{C} 1$ level and among these words, the most frequently used word is Selçuklu (Seljukian) with 82 repetitions. In terms of frequency, the word is followed by medrese (madrasah) (67), Uygur (Uigur) (57), derle- (to compile) (53), and veli (saint) (53). The word veli, which is also used as a personal name in Turkish, is the cult of saints in the cultural corpus and means a person with spiritual powers as in the context of religious beliefs: "Similar legends are told about different saints in many cities of Anatolia." (Türk Dil Kurumu, 2021). In the C1 level cultural word list there are historical words such as Selçuklu (Seljukian), arkaik (archaic), and Helenistik (Hellenistic). In addition, there are religious words such as veli (saint), Hızır (Khidr) and evliya (saint). Cultural words also include the word büyük (great) in the $\mathrm{C} 1$ list. In the research corpus, this word is used with its $4^{\text {th }}$ meaning (superior, great) in the Contemporary Turkish Dictionary of Turkish Language Association (2021) as in the example: "I learned that the great (superior) photographer Ara Güler was dead." This meaning of the word büyük was levelled as C1. C1 level place names in the corpus are Antakya (a city in Turkey) and Halep (Aleppo). C1 level adjectives include üstün (superior), belirgin (apparent), and idari (administrative). And the 
verbs in this list are derle- (to compile), uzan- (to lie down), and oluştur- (to create). (For the complete list of words, see Appendix 5).

\subsubsection{C2 Level Cultural Word List}

There are 33 words in C2 level and among these words, the most frequently used word is a geographical name, Altay (Altai) with 37 repetitions. In terms of frequency, the word Altay is followed by şeyh (sheikh) (33), paleolitik (Paleolithic) (33), Bedri Rahmi Eyüboğlu (10), and Edirne Sarayı (Edirne Palace) (10). Cultural concepts are widely used at C2 level. At this level, there are names of buildings such as Habib-i Neccar Camii (a mosque), Yakutiye Medresesi (a madrasah), and personal names such as Bedri Rahmi Eyüboğlu and Sultan Keykubad (Seljukian sultan). There are also food names such as dartı yemeği (a dish), ecevit çorbası (a soup), höşmerim (a dessert). (For the complete list of words, see Appendix 6).

\subsection{Differences of Cultural Words by Proficiency Levels in Terms of Frequency}

At this stage of the study, the differences of cultural words in terms of frequency have been studied. $100 \mathrm{~A} 1$ level words with a frequency between 405 and 8, 111 A2 level words with a frequency between 178 and 8, $121 \mathrm{~B} 1$ level words with a frequency between 72 and 8, 92 B2 level words with a frequency between 108 and 8, 55 C1 level words with a frequency between 82 and 8, and $33 \mathrm{C} 2$ level words with a frequency between 37 and 8 have been included within the scope of this research. In order to select the analysis appropriate for the study data, first, a normality test has been applied and the results are shown in Table 2.

Table 2. Table of the normality test of the frequency data

\begin{tabular}{|c|c|c|c|c|c|c|c|c|c|c|}
\hline & \multicolumn{2}{|c|}{ Proficiency Level } & \multirow[t]{2}{*}{ Statistic } & \multirow{2}{*}{$\begin{array}{c}\text { Std. } \\
\text { Error }\end{array}$} & \multicolumn{3}{|c|}{ Kolmogorov-Smirnov } & \multicolumn{3}{|c|}{ Shapiro-Wilk } \\
\hline & & & & & Statistic & $\mathrm{df}$ & Sig. & Statistic & $\mathrm{df}$ & Sig. \\
\hline \multirow[t]{12}{*}{ Frequency } & $\mathrm{A} 1$ & Skewness & 3.763 & 0.241 & \multirow{2}{*}{.230} & \multirow{2}{*}{100} & \multirow{2}{*}{.000} & \multirow{2}{*}{.640} & \multirow{2}{*}{100} & \multirow{2}{*}{.000} \\
\hline & & Kurtosis & 19.913 & 0.478 & & & & & & \\
\hline & \multirow[t]{2}{*}{$\mathrm{A} 2$} & Skewness & 2.194 & 0.229 & \multirow{2}{*}{.229} & \multirow{2}{*}{111} & \multirow{2}{*}{.000} & \multirow{2}{*}{.720} & \multirow{2}{*}{111} & \multirow{2}{*}{.000} \\
\hline & & Kurtosis & 5.050 & 0.455 & & & & & & \\
\hline & \multirow[t]{2}{*}{ B1 } & Skewness & 2.178 & 0.220 & \multirow{2}{*}{.246} & \multirow{2}{*}{121} & \multirow{2}{*}{.000} & \multirow{2}{*}{.694} & \multirow{2}{*}{121} & \multirow{2}{*}{.000} \\
\hline & & Kurtosis & 4.676 & 0.437 & & & & & & \\
\hline & \multirow[t]{2}{*}{$\mathrm{B} 2$} & Skewness & 2.144 & 0.251 & \multirow{2}{*}{.235} & \multirow{2}{*}{92} & \multirow{2}{*}{.000} & \multirow{2}{*}{.720} & \multirow{2}{*}{92} & \multirow{2}{*}{.000} \\
\hline & & Kurtosis & 4.993 & 0.498 & & & & & & \\
\hline & \multirow[t]{2}{*}{$\mathrm{C} 1$} & Skewness & 1.885 & 0.322 & \multirow{2}{*}{.275} & \multirow{2}{*}{55} & \multirow{2}{*}{.000} & & -5 & 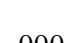 \\
\hline & & Kurtosis & 3.246 & 0.634 & & & & .707 & & .000 \\
\hline & $\mathrm{C} 2$ & Skewness & 3.409 & 0.409 & 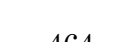 & 20 & م & r & م & 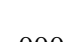 \\
\hline & & Kurtosis & 11.100 & 0.798 & .464 & 30 & .000 & $.4 \angle 5$ & 30 & .000 \\
\hline
\end{tabular}

As a result of the analysis, it has seen that the cultural words are not normally distributed according to the proficiency levels (A1, A2, B1, B2, C1, and C2) in terms of their frequency $(p=.00<p=.05)$. As a result of the normality test implemented on the study data, the Kruskal-Wallis test has been applied to examine the difference 
between the frequencies of cultural words according to the levels and the results are shown in Table 3.

Table 3. Kruskal-Wallis test result showing the differences of cultural words according to proficiency levels

\begin{tabular}{lcccccccc}
\hline & $\mathrm{N}$ & Mean & $\begin{array}{c}\text { Std. } \\
\text { Deviation }\end{array}$ & Minimum & Maximum & df & $\mathrm{X}^{2}$ & $\mathrm{p}$ \\
$\begin{array}{l}\text { frequency } \\
\begin{array}{l}\text { Proficiency } \\
\text { level }\end{array}\end{array}$ & 512 & 27.64 & 33.58 & 8 & 405 & 5 & 103.531 & .000 \\
\hline
\end{tabular}

According to Table 3, it has been seen that there is a difference in the distribution of cultural words according to proficiency levels (A1, A2, B1, B2, C1 and C2) in terms of frequency $(p=.00<p=.05)$. The differences between the levels have been analyzed with the Mann-Whitney $U$ test and the result is shown in Table 4.

Table 4. Mann-Whitney $\mathrm{U}$ table showing the differences between the frequencies and the proficiency levels of cultural words

\begin{tabular}{|c|c|c|c|c|c|c|c|}
\hline & level & $\mathrm{N}$ & Mean Rank & $\begin{array}{l}\text { Sum of } \\
\text { Ranks }\end{array}$ & $\begin{array}{r}\text { Mann- } \\
\text { Whitney U }\end{array}$ & Z & $\mathrm{p}$ \\
\hline \multirow{10}{*}{$\begin{array}{l}\text { Frequency } \\
\text { of cultural } \\
\text { words }\end{array}$} & $\mathrm{A} 1$ & 100 & 118.93 & 11892.50 & \multirow[t]{2}{*}{4257.50} & \multirow[t]{2}{*}{-2.921} & \multirow[t]{2}{*}{0.003} \\
\hline & $\mathrm{A} 2$ & 111 & 94.36 & 10473.50 & & & \\
\hline & A2 & 111 & 138.74 & 15400 & \multirow{2}{*}{4247} & \multirow{2}{*}{-4.851} & \multirow{2}{*}{0.000} \\
\hline & B1 & 121 & 96.10 & 11628 & & & \\
\hline & B1 & 121 & 99.43 & 12031.50 & \multirow{2}{*}{4650.50} & \multirow{2}{*}{-2.065} & \multirow{2}{*}{0.039} \\
\hline & B2 & 92 & 116.95 & 10759.50 & & & \\
\hline & B2 & 92 & 78.24 & 7198.50 & \multirow{2}{*}{2139.50} & \multirow{2}{*}{-1.571} & \multirow{2}{*}{0.116} \\
\hline & $\mathrm{C} 1$ & 55 & 66.90 & 3679.50 & & & \\
\hline & $\mathrm{C} 1$ & 55 & 50.71 & 2789 & \multirow{2}{*}{566} & \multirow{2}{*}{-3.003} & \multirow{2}{*}{0.003} \\
\hline & $\mathrm{C} 2$ & 33 & 34.15 & 1127 & & & \\
\hline
\end{tabular}

When Table 4 is examined, a statistically significant difference has been found between A1 and A2 (p=.003<p=.05); between A2 and B1 ( $=.000<p=.05)$; between B1 and B2 $(p=.039<p=.05)$ and between $\mathrm{C} 1$ and $\mathrm{C} 2(\mathrm{p}=.003<\mathrm{p}=.05)$. However, no difference has been found between $\mathrm{B} 2$ and $\mathrm{C} 1$ level words in terms of frequency $(p=.116>p=.05)$.

\section{Discussion}

In this study, cultural words have been discussed in terms of teaching Turkish as a foreign language. Frequency constitutes the basic criterion in the selection of cultural words by separating them from general usage words. The frequency criterion was previously used by Coxhead (2000) in the selection of academic words and Coxhead used the first 2000 words in this study. Corpus linguistics methods and techniques have been used to reach word frequencies. The corpus in the study is a special purpose corpus created to obtain cultural words. Special purpose corpora are 
developed depending on the research question (Özkan, 2013). Such corpora are used for certain purposes such as investigating vocabulary in technical fields such as chemistry and nursing (Valipouri \& Nassaji, 2013; Yang, 2015), broader vocabulary such as academic language (Ackermann \& Chen, 2013), or the functions of grammatical units (Aydemir, 2010). In this study, texts for cultural information have been selected as data sources, and it has been aimed to obtain the words that have cultural value or are frequently used in creating cultural texts. In the study, cultural words have been obtained both for the learners to use in their everyday communication and for them to learn about Turkey in the language learning process of learners of Turkish as a foreign language with communicative purposes and the distribution of these words according to the proficiency levels (A1/2, B1/2, and C1/2) in teaching Turkish as a foreign language has been studied.

100 A1 level cultural words consist of food names such as çorba (soup) and names of food related objects such as yemek kaşı̆̆ (tablespoons). Since A1 is the first level for a language learner and the need for food is one of the basic requirements, these words should be taught at A1 level. In addition, personal names frequently used by Turks such as Ali, Kemal and Mehmet (shortened version of the word Muhammet in Arabic) are also at A1 level. From these findings, it can be concluded that personal names specific to Turks should be at A1 level for cultural introduction. It is also culturally important to include people with Turkish personal names at this level in the selection of A1 level texts. There are 111 words at A2 level, and words at this level include food words such as salça (tomato paste), yağ (oil), soğan (onion) and food related verbs such as kaynat- (to boil), rendele- (to grate), kavur- (to roast). In this respect, it can be said that cultural words between A1 and A2 show a conceptual transition. Besides, it is seen that regional names such as Ege (Aegean) and Karadeniz (Black Sea) and city names such as Muğla and Erzurum are used at this level. Since there is no agreement between experts on the level of city names to be included, the following method has been followed in the levelling of city names: Ankara, in the cultural word list, has been included in the A1 level word list due to its being the capital and Istanbul due to its high recognition. Metropolitan cities in the cultural word list such as Adana, Gaziantep, and Şanlıurfa have been levelled as A2, and cities that do not have metropolitan status such as Kütahya, Bolu and Amasya have been levelled as B1 and the list has been finalized. At this point, the word metropolitan refers to cities with a population of more than 750,000 according to the Metropolitan Municipality Law (Law No: 5216) and transformed into a metropolitan municipality by law. Moreover, historical personalities such as Fatih Sultan Mehmet has been included in A2 level. B1 is the level including the most academic words (121 words). It is seen that the conceptual diversity of cultural words increases at this level. The names of nonmetropolitan cities as well as touristic places and districts such as Afrodisias and Safranbolu have also been included in this level. There are 92 words in B2 level including passive verbs like konul- (to be put) and düşünül- (to be considered), food words that are more cultural and are used in certain regions of Turkey like dügün çorbası (a soup) and çökelek (cottage cheese), and parts of religious buildings like 
minare (minaret). 55 words at $\mathrm{C} 1$ level include words which not only are academic concepts but also have historical value such as Türk Edebiyatı (Turkish Literature), helenistik (Hellenistic), and kronolojik (chronological), and food names such as börülce (cowpea), which are used in much more local and special dishes. And, 33 words at C2 level include scientists or historical personalities such as Mimar Kemalettin Bey (an architect), Pertev Naili Boratav (a folklorist), and Sultan Abdulaziz (an Ottoman sultan). The teaching of these concepts carries a more intellectual level compared to other levels. In addition, at this level, cultural dishes such as dartı yemeği (a dish) and Ecevit çorbası (a soup), which are much more local to use than $\mathrm{C} 1$, have been included. According to the findings, $\mathrm{C} 1$ level includes academic information in terms of cultural words, while $\mathrm{C} 2$ level includes academic and a more in-depth intellectual level. The frequency of cultural words increase from $\mathrm{A} 1$ to $\mathrm{B} 1$ and it is understood that B1 level contains the highest number of cultural words. Up to B1 level, A1 and A2 level cultural words include general cultural knowledge words like food and object words that can be used in everyday conversations and better known metropolitan names. However, at the B1 level, it is seen that the number of cultural words has increased with the diversity of the contexts. Within the scope of the study, it has been seen that there is a statistically significant difference in word frequencies between $\mathrm{A} 1$ and $\mathrm{A} 2 ; \mathrm{A} 2$ and $\mathrm{B} 1$; and $\mathrm{B} 1$ and B2 levels. According to these findings, it is understood that there is a significant increase in the frequency of cultural words from A1 level to B1 level. However, there is a decrease in the frequency of words between B1 level and B2 level. The reason for this is that the cultural words used from B2 on starts to have more special meanings with conceptual values. Thus, it is seen that the number of use of cultural words decreases but becomes more intense in terms of information value. For instance, while çorba (soup) as a common food word is levelled as A1, tarhana çorbası (tarhana soup) that is a common soup in Turkey is levelled as A2. However, düğün çorbası (a soup) which is relatively less known is levelled as B2 and Ecevit çorbası (a soup) which is used only in certain regions is levelled as $\mathrm{C} 2$. When the findings are studied in terms of their frequency and conceptual values, it is observed that the conceptual value has a meaningful value that narrows from $\mathrm{A} 1$ to $\mathrm{C} 2$ as expected, while the frequency increases from $\mathrm{A} 1$ to $\mathrm{B} 1$ and the number and frequency of cultural words decrease from B1. The fact that there is no difference between B2 and $\mathrm{C} 1$ in terms of the frequency of cultural words suggests that the sufficient distinction at the cultural level is not yet clear between these two levels in terms of teaching Turkish as a foreign language. For instance, as a result of expert opinions, çökelek (cottage cheese) is levelled as B2, while the semizotu (purslane) is levelled as C1 and the frequency of both is determined as 9 in the cultural corpus. At this point, the study on identifying Turkish culture descriptors for B1 level in teaching Turkish as a foreign language (Fişekçioğlu, 2019) should be expanded the scope of the study to other proficiency levels and the cultural word lists customized according to the proficiency levels should be extended by considering these descriptors.

\section{Conclusions}


As a result of this research, it has been seen that cultural words increase in number from A1 to B1 level in teaching Turkish as a foreign language, and the highest number of words is at B1 level. The fact that the highest number of words are at the B1 level and that these words have more conceptual diversity than other levels has led to the idea that B1 level may be a threshold in cultural vocabulary teaching. However, it would be useful to test this finding with different studies. It is clear that the concept values of cultural words range from general to specific from A1 to $\mathrm{C} 2$ level, but the diversity of the contexts of cultural words increases from B1 level. The vocabulary list obtained as a result of the study can be used by teachers of Turkish as a foreign language in both purposeful vocabulary and concept instruction practices and in preparing course materials and material books. Besides, both the word list obtained from this study and different lists obtained from the cultural corpora that will be formed in a wider scope in future studies will provide individual words data for preparing a cultural dictionary for Turkish, like the Australian Cultural Dictionary.

In conclusion, the findings are expected to provide a foresight for material designers and teachers about the concepts to be included in the teaching of culture within the scope of foreign language teaching. In addition, it is thought provide a basis for different studies in terms of the type and proficiency level of cultural concepts in foreign language teaching.

\section{The Research and Publication Ethics Statement}

The main focus of this study was based on corpus data; therefore, it was not required to obtain an ethics approval.

\section{The Conflict of Interest Statement}

In line with the statement of Committee on Publication Ethics (COPE), I hereby declare that I had no conflicting interests regarding any parties of this study.

\section{References}

Ackermann, K. \& Chen, Y-H. (2013). Developing the academic collocation list (ACL) - A corpus driven and expert-judged approach. Journal of English for Academic Purposes, 12(4), 235247.

Aksan, D. (1971). Kavram alanı-kelime ailesi ilişkileri ve Türk yazı dilinin eskiliği üzerine. Türk Dili Araştırmaları Yıllı̆̆ı Belleten, 338(1), 254-262.

Aksan, Y., Aksan, M., Mersinli, Ü. \& Demirhan, U. U. (2017). A Frequency dictionary of Turkish core vocabulary for learners. London: Routledge Pub.

Alimjanova, G. M. (2016). Karşılaştırmalı kültürdilbilim, dil-kültür-insan. Ankara: Gazi Yayınevi.

Aydemir, A. İ. (2010). Türkçede zaman ve görünüş sistemi. Ankara: Grafiker Yayınları

Baydak, A. V., Scharioth, C. \& Il'yashenko, A. (2015). Interaction of language and culture in the process of international education. Procedia - Social and Behavioral Sciences, 215(1), $14-18$.

Brezina, V. \& Gablasova, D., (2013). Is there a core general vocabulary? Introducing the new general service list. Applied Linguistics, (36)1, 1-23. 
Coxhead, A. (2000). A New academic word list. TESOL Quarterly, 34(2), 213-238.

Coxhead, A. (2011). The academic word list 10 years on: Research and teaching implications. TESOL Quarterly, 45(2), 355-362.

Dang, T. N. Y. \& Webb, S. (2014). The lexical profile of academic spoken English. English for Specific Purposes (33)1, 66-76.

Fişekçioğlu, A. (2019). Yabancı dil olarak Türkçe öğretiminde diller için Avrupa ortak öneriler çerçevesi ölçütlerine göre Türk kültürü tanımlayıcılarının oluşturulması: B1 dil düzeyi model önerisi. (Doctoral dissertation, Çanakkale Onsekiz Mart Üniversitesi, Eğitim Bilimleri Enstitüsü). Çanakkale.

Gardner, D. \& Davies, M., (2014). A New academic vocabulary list. Applied Linguistics, 35(3), $305-327$.

Göz, İ. (2003). Yazllı Türkçenin kelime sıklı̆̆ı sözlüğü. Ankara: Türk Dil Kurumu Yayınları.

Haviland, A. W., Pirins, E. L. H., Wairath, D. \& Mc Bride, B. (2006). Kültürel antropoloji. Trans.: Deniz Erguvan. İstanbul: Kaknüs Yayınları.

Hofstede, G. (2011). Dimensionalizing cultures: The Hofstede model in context. Online Readings in Psychology and Culture, 2(1). https://doi.org/10.9707/2307-0919.1014.

House, J. (2020). Translation as a prime player in intercultural communication. Applied Linguistics, 41(1), 10-29.

Hyland, K. \& Tse, P. (2007). Is there an "Academic Vocabulary"?, TESOL Quarterly, 41(2), 235-253.

Khani, R. \& Tazik, K. (2013). Towards the development of an academic word list for applied linguistics research articles. RELC Journal, 44(2), 209-232.

Klimova, B. F. (2014). Using corpus linguistics in the development of writing. Procedia - Social and Behavioral Sciences, 141(1) $124-128$.

Koizumi, R. \& In'nami, Y. (2013). Vocabulary knowledge and speaking proficiency among second language learners from novice to intermediate levels. Journal of Language Teaching and Research, 4(5), 900-913.

Kramsch, C., (2006). Culture in language teaching. In K. Brown (Eds.). Encyclopedia of Language \& Linguistics (2 ${ }^{\text {nd }}$ Ed.) (pp. 322-329). Amsterdam: Elsevier Science.

Kremmel, B. (2016). Word families and frequency bands in vocabulary tests: Challenging Conventions, TESOL Quarterly, 50(4), 976-987.

Lei, L. \& Liu, D. (2016). A new medical academic word list: A corpus-based study with enhanced methodology. Journal of English for Academic Purposes, (22), June, 42-53.

Lozano, C. \& Mendikoetxea, A. (2013). Learner corpora and second language acquisition: The design and collection of CEDEL2. In A. Díaz-Negrillo, N. Ballier \& P. Thompson (Eds.), Automatic treatment and analysis of learner corpus data (pp. 65-100). Amsterdam: John Benjamins.

McEnery, T. \& Hardie, A. (2012). Corpus linguistics: method, theory and practice. Cambridge: Cambridge University Press.

Mikhaleva, L. V. \& Régnier, J. C. (2014). Parallel Study of Native and Target-language Cultures in Foreign Language Teaching. Procedia - Social and Behavioral Sciences, 154 (1), $118-121$

Schmitt, N. (2008). Instructed second language vocabulary learning. Language Teaching Research, 12(3), 329-363.

Sergeyeva, T. G. (2014). Kültürdilbilimde temel birimlerin tanımlanması üzerine, In O. Kozan (Eds.). Kültürdilbilim temel kavramlar ve sorunlar, (pp: 51-56). Ankara: Gazi Kitabevi. 
Sinclair, J. (2005). Corpus and text-basic principles. In M. Wynne (Ed.), Developing linguistic corpora: A guide to good practice (pp. 1-16). Oxford: Oxbow Books. Retrieved from /http://ahds.ac.uk/linguistic-corpora on February 20, 2007.

Sharifian, F. (2011). Cultural conceptualisations and language theoretical framework and applications. Amsterdam/ Philadelphia: John Benjamins Publishing.

Sharifian, F. (2017). Cultural linguistics and linguistic relativity. Language Sciences, 59 (January), 83-92.

Smith, P. \& Riley, A. (2016). Kültürel kurama giriş. Trans.: S. Güzelsarı \& İ. Gündoğdu. Ankara: Dipnot Yayınları.

Staehr, L. S. (2008). Vocabulary size and the skills of listening, reading and writing. Language Learning Journal, 36(2), 139- 152.

Stoykova, V. (2014). Teaching corpus linguistics. Procedia - Social and Behavioral Sciences, 143(1), $437-441$.

Ölker, G. (2011). Yazılı Türkçenin kelime sıllı̆̆ı sözlü̆̆̈̈. Konya: Kömen Yayınları.

Oxford, R. (1996). Why is culture important for language learning strategies? In R. Oxford (Ed.), Language strategies around the World: Cross-cultural perspectives, pp: IX-XV. Hawai: University of Hawai'i Press.

Özkan, B. (2012). Türkiye Türkçesinde belirteçlerle fiillerin birlikte kullanılması ve eş dizimlilikleri. Ankara: Türk Dil Kurumu Yayınları.

Özkan B. (2013). Derlem dilbilim çalişmalari ve dil öğretimi. In M. Durmuş \& A. Okur (Eds.). Yabancılara Türkçe öğretimi el kitabı, (pp: 433-451). Ankara: Grafiker yay.

Matthews, J. (2018). Vocabulary for listening: Emerging evidence for high and mid-frequency vocabulary knowledge. System, 72(1), 23-36.

McLean, S., Stewart, J. \& Batty, A. O. (2020). Predicting L2 reading proficiency with modalities of vocabulary knowledge: A bootstrapping approach. Language Testing, 37(3), 389-411.

Michelson, K. (2018). Teaching culture as a relational process through a multiliteracies-based global simulation. Language, Culture and Curriculum, 31(1), 1-20.

Masrai, A. \& Milton, J. (2018). Measuring the contribution of academic and general vocabulary knowledge to learners' academic achievement. Journal of English for Academic Purposes, 31(1), 44-57.

Tahiroğlu, B. T., (2008). Derlem dil bilimi ve güncel gelişmeler. Uluslararası Türk Dili Kurultayı Bildirileri kitabı, Ankara: TDK yayınları.

Türk Dil Kurumu, (2005). Türkçe Sözlük. Ankara: Türk Dil Kurumu Yayınları.

Uzum, B., Yazan, B., Zahrawi, S., Bouamer, S. \& Malakaj, E. (2021). A comparative analysis of cultural representations in collegiate world language textbooks (Arabic, French, and German). Linguistics and Education, 61(February), 1-12.

Valipouri, L. \& Nassaji, H. (2013). A corpus-based study of academic vocabulary in chemistry research articles. Journal of English for Academic Purposes, 12, 248-263.

Vongpumivitch, V., Huang, J-Y \& Chang, Y-C. (2009). Frequency analysis of the words in the Academic Word List (AWL) and non-AWL content words in applied linguistics research papers, English for Specific Purposes, 28(1), 33-41.

Yang, M. N. (2015). A nursing academic word list, English for Specific Purposes, 37(January), $27-38$.

https://dictionary.cambridge.org/dictionary/learner-english/church, Accessed on 02.05.2020

https://dictionary.cambridge.org/dictionary/learner-english/mosque? $q=$ mosque+, Accessed on 02.05.2020. 
https://dictionary.cambridge.org/dictionary/learner-english/king, Accessed on 02.05.2020. https://www.kulturportali.gov.tr, Accessed on 03.06.2020.

https://www.resmigazete.gov.tr/eskiler/2004/07/20040723.htm\#1, Accessed on 10.05.2020.

\section{Appendix A. Appendices}

\section{A.1. Appendix 1 - A1 Level Cultural Word List}

\begin{tabular}{|c|c|c|c|c|}
\hline Türk & 405 & limon & 46 & kaşık \\
\hline su bardağ & 226 & pirinç & 44 & İbrahim \\
\hline çorba & 219 & ahmet & 43 & salata \\
\hline eski & 147 & Ali & 43 & mustafa \\
\hline mimar & 141 & yüksek & 42 & derin \\
\hline soğan & 132 & yeşil & 40 & Moğolistan \\
\hline Atatürk & 106 & Kemal & 39 & genç \\
\hline türkiye & 102 & kurbağa & 39 & Suriye \\
\hline tereyağ1 & 101 & firın & 38 & hoş \\
\hline tatll & 96 & tavuk & 37 & manzara \\
\hline Türkçe & 94 & iyi & 36 & temiz \\
\hline İstanbul & 89 & taze & 35 & yabancı \\
\hline biber & 85 & genel & 33 & Allah \\
\hline kuru & 85 & lezzetli & 33 & damat \\
\hline yemek kaşığg & 85 & soğuk & 33 & üzüm \\
\hline tencere & 84 & çin & 32 & Fransiz \\
\hline Ankara & 82 & sosyal & 32 & mustafa kemal \\
\hline sicak & 79 & at & 31 & mercimek \\
\hline zengin & 78 & değişik & 31 & Moğol \\
\hline dua et- & 75 & erken & 30 & tuzlu \\
\hline ceviz & 70 & uygun & 29 & arapça \\
\hline güzel & 68 & afiyet olsun & 27 & fincan \\
\hline merkez & 64 & kitap & 27 & mavi \\
\hline çay kaşığı & 59 & beyaz & 26 & piknik \\
\hline yakın & 59 & maydanoz & 26 & yllan \\
\hline örnek & 58 & Hasan & 25 & hall \\
\hline yoğurt & 57 & mimarlık & 25 & taraf \\
\hline Mehmet & 56 & gül & 24 & Irak \\
\hline kırmızı & 55 & ünlü & 24 & marul \\
\hline geniş & 54 & findlk & 23 & koridor \\
\hline peynir & 51 & harika & 22 & boya \\
\hline dolu & 50 & fasulye & 21 & karşılıklı \\
\hline sarımsak & 48 & renkli & 21 & \\
\hline domates & 47 & litre & 21 & \\
\hline
\end{tabular}




\section{A.2. Appendix 2 - A2 Level Cultural Word List}

\begin{tabular}{|c|c|c|c|c|}
\hline osmanlı & 178 & kisık & 33 & kase \\
\hline Anadolu & 167 & köşk & 31 & cevizli \\
\hline yağ & 159 & ziyaretçi & 31 & gümüş \\
\hline kültür & 142 & tabiat & 28 & turistik \\
\hline servis et- & 128 & uzaklık & 28 & müslüman \\
\hline hamur & 117 & tarif et- & 28 & etli yemek \\
\hline ekle- & 107 & Gaziantep & 26 & yaprak sarması \\
\hline sahip ol- & 94 & atölye & 26 & kayseri \\
\hline yaklaşık & 92 & küp & 26 & muğla \\
\hline doğra- & 78 & pul biber & 26 & bal \\
\hline çeşme & 75 & llık & 26 & batılı \\
\hline salça & 73 & inşa et- & 24 & içecek \\
\hline ün & 72 & aşure & 22 & sebzeli \\
\hline avrupa & 68 & milli & 22 & tabak \\
\hline karabiber & 67 & Bursa & 22 & ege \\
\hline kaynat- & 64 & Konya & 20 & karadeniz \\
\hline geleneksel & 60 & erit- & 20 & lezzet \\
\hline tarhana çorbası & 60 & dolma & 19 & rendele- \\
\hline menü & 56 & kuşbaşı & 19 & dikkat et- \\
\hline savaş & 55 & demet & 18 & kabak \\
\hline sıvı yağ & 55 & ziyaret saatleri & 18 & dikdörtgen \\
\hline özel & 53 & yufka & 18 & kıymalı \\
\hline servis yap- & 53 & islam & 18 & hiristiyan \\
\hline doğal & 50 & Şanlıurfa & 17 & keyifli \\
\hline nohut & 50 & kilometre & 17 & yumuşak \\
\hline dökül- & 49 & meydana gel- & 17 & kavur- \\
\hline nane & 48 & erzurum & 16 & kızar- \\
\hline baklava & 45 & bez & 16 & közlen- \\
\hline bulgur & 44 & dereotu & 16 & politik \\
\hline kuru soğan & 44 & kayak & 16 & efsane \\
\hline helva & 40 & adana & 16 & soğuma \\
\hline buğday & 39 & bolluk & 15 & bulgurlu \\
\hline Hatay & 37 & sos & 15 & incir \\
\hline kıyma & 36 & güçlü & 12 & indir- \\
\hline mardin & 35 & kartal & 12 & kaymak \\
\hline kutsal & 34 & şirin & 12 & kayna- \\
\hline zeytinyağı & 33 & Fatih Sultan & 12 & \\
\hline tava & 33 & Me & & \\
\hline
\end{tabular}

\section{A.3. Appendix 3 - B1 Level Cultural Word List}

antik

72

şelale

Edirne 


\begin{tabular}{|c|c|c|c|c|}
\hline kule & 56 & siyasi & 16 & budist \\
\hline eşsiz & 52 & Bolu & 15 & çorum \\
\hline doğal & 50 & çoban & 15 & değerli \\
\hline yazılı & 46 & sopa & 15 & düzgün \\
\hline vadi & 46 & rulo & 14 & etkili \\
\hline avlu & 46 & dikkat çek- & 13 & geçici \\
\hline oklava & 43 & geometrik & 12 & gizli \\
\hline göç & 42 & sanatsal & 12 & hazırlanış \\
\hline islat- & 37 & tarihsel & 12 & isimli \\
\hline ters & 35 & devam et- & 12 & kars \\
\hline yerleşik & 33 & gazi & 12 & keçi \\
\hline pul & 29 & nemrut & 12 & kesin \\
\hline beğeni & 29 & safranbolu & 12 & slğır \\
\hline ebru sanatı & 29 & asma & 11 & tapınak \\
\hline muhteşem & 27 & coğrafi & 11 & tarihli \\
\hline bereket & 26 & dokuma & 11 & venedik \\
\hline sözlü & 26 & ibadet & 11 & avcl \\
\hline bulun- & 25 & Amasya & 11 & gerçek \\
\hline miras & 24 & manda & 11 & hayvancılık \\
\hline dini & 23 & bilim adamı & 10 & toplan- \\
\hline gezdir- & 23 & cumhuriyet dönemi & 10 & aksaray \\
\hline yaygin & 22 & temsil et- & 10 & asll \\
\hline Kurtuluş Savaşı & 21 & canlı & 10 & av \\
\hline kilis & 21 & denizli & 10 & çadır \\
\hline adlandır- & 20 & dikkate al- & 10 & düzce \\
\hline sivri & 20 & gelişme & 10 & düzenli \\
\hline Kütahya & 20 & iri & 10 & evlenme \\
\hline yoğun & 20 & kalınlık & 10 & hayran \\
\hline han (I) (sultan) & 20 & sarp & 10 & kilometrelik \\
\hline kap & 20 & uzunluk & 10 & kişisel \\
\hline kesme & 20 & yükseklik & 10 & konaklama \\
\hline Meryem Ana & 19 & afrodisias & 10 & benzerlik \\
\hline yuvarlak & 19 & osmanlı devleti & 10 & cenaze \\
\hline görkemli & 18 & bartın & 10 & genişlik \\
\hline dana & 17 & ulusal & 10 & gözetleme \\
\hline toplu & 17 & yeter & 10 & aşı \\
\hline ortak & 17 & özen göster- & 10 & çömlek \\
\hline \multirow{3}{*}{$\begin{array}{l}\text { Türkiye büyük } \\
\text { millet meclisi } \\
\text { uluslararası } \\
\text { bilge }\end{array}$} & 17 & şam & 10 & koruma \\
\hline & 16 & çuval & 10 & \\
\hline & 16 & afyon & 9 & \\
\hline
\end{tabular}




\section{A.4. Appendix 4 - B2 Level Cultural Word List}

\begin{tabular}{|c|c|c|c|c|}
\hline pişiril- & 108 & yöresel & 22 & görül- \\
\hline karıştırıl- & 85 & dövül- & 21 & simgele- \\
\hline karagöz-hacivat & 84 & ekonomik & 20 & ticarî \\
\hline kazı & 75 & Mimar Sinan & 20 & düğün çorbası \\
\hline roma dönemi & 68 & dizil- & 19 & yağlı boya \\
\hline haşlan- & 56 & açıl- & 17 & dövülmüş ceviz \\
\hline kültürel & 53 & klasik & 17 & barındir- \\
\hline uygulama & 53 & misir unu & 17 & tarihlen- \\
\hline yaptıril- & 51 & çıkarıl- & 16 & döşe- \\
\hline kurul- & 47 & katıl- & 16 & hediyeleşme \\
\hline yağmur duası & 43 & kemer & 16 & çam \\
\hline çalışma & 42 & tabiat parkı & 15 & çökelek \\
\hline bırakıl- & 42 & minare & 14 & dinsel \\
\hline arkeoloji & 41 & unesco & 13 & karşlık \\
\hline türbe & 41 & kemik suyu & 12 & kavim \\
\hline toplumsal & 36 & pişmiş & 12 & korunma \\
\hline kalıntı & 34 & selimiye cami & 12 & sahiplik \\
\hline ahşap & 34 & Orta Asya Türkleri & 12 & seramik \\
\hline ritüel & 34 & gelişmiş & 12 & şema \\
\hline arkeolojik & 33 & akademi & 11 & karbonat \\
\hline motif & 32 & bakla & 11 & kukla \\
\hline saat kulesi & 30 & bronz & 11 & bakıl- \\
\hline anitsal & 29 & ilkel & 11 & bakır \\
\hline göçebe & 26 & külliye & 11 & belirt- \\
\hline anlaşıl- & 26 & sümela manastırı & 11 & dönüştürül- \\
\hline antik kent & 25 & şüphesiz & 11 & düşünül- \\
\hline mermer & 23 & türkistan & 11 & harç \\
\hline arkeoloji müzesi & 23 & bilimsel & 11 & konul- \\
\hline destan & 22 & taş köprü & 10 & içer- \\
\hline taç & 22 & ata & 10 & konak \\
\hline
\end{tabular}

iftar 22

barınak $\quad 10$

\section{A.5. Appendix 5 - C1 Level Cultural Word List}

$\begin{array}{llll}\text { selçuklu } & 82 & \text { bozkır } & 35 \\ \text { medrese } & 67 & \text { karışım } & 33 \\ \text { uygur } & 57 & \text { kabartma } & 32 \\ \text { derle- } & 53 & \text { simge } & 32 \\ \text { veli } & 51 & \text { han (büyük bina) } & 27 \\ \text { bizans } & 44 & \text { hıdırellez } & 27 \\ \text { büyük } & 43 & \text { Osman Hamdi } & \\ \text { uzan- } & 38 & \text { Bey } & 25\end{array}$

$\begin{array}{ll}\text { Türk El Sanatları } & 19 \\ \text { antakya } & 18 \\ \text { hızır } & 18 \\ \text { kubbe } & 18 \\ \text { göktürk } & 17 \\ \text { Oğuz Kağan } & \\ \text { Destanı } & 17 \\ \text { ihlara vadisi } & 13\end{array}$




$\begin{array}{ll}\text { egemen } & 12 \\ \text { Hıdırbey Musa } & \\ \text { Ağacı } & 12 \\ \text { bayezid külliyesi } & 10 \\ \text { bozkır kültürü } & 10 \\ \text { ısırgan } & 10 \\ \text { mineral } & 10 \\ \text { müzecilik } & 10 \\ \text { oluştur- } & 10 \\ \text { özgün } & 10 \\ \text { tasvir } & 10 \\ \text { kutadgu bilig } & 10\end{array}$

$\begin{array}{ll}\text { büyüsel } & 10 \\ \text { hat sanatı } & 10 \\ \text { arkaik } & 9 \\ \text { beze } & 9 \\ \text { börülce } & 9 \\ \text { etnik } & 9 \\ \text { etnografya } & 9 \\ \text { kronolojik } & 9 \\ \text { paralel } & 9 \\ \text { saklı } & 9 \\ \text { semizotu } & 9 \\ \text { tan } & 9\end{array}$

$\begin{array}{ll}\text { üstün } & 9 \\ \text { tophane } & 9 \\ \text { belirgin } & 8 \\ \text { evliya } & 8 \\ \text { halep } & 8 \\ \text { helenistik } & 8 \\ \text { idari } & 8 \\ \text { iskân } & 8 \\ \text { kâtip } & 8 \\ \text { Türk edebiyatı } & 8\end{array}$

A.6. Appendix 6-C2 Level Cultural Word List

\begin{tabular}{llllll} 
altay & 37 & dartı yemeği & 9 & buhara & 8 \\
şeyh & 33 & ecevit çorbası & 9 & fasıl & 8 \\
paleolitik & 20 & höşmerim & 9 & kerpiç & 8 \\
Bedri Rahmi Eyüboğlu & 10 & Hüseyin Avni Lifij & 9 & Köğmen dağları & 8 \\
edirne sarayı & 10 & konargöçerlik & 9 & Mimar Kemalettin Bey & 8 \\
gazneli & 10 & Mimar Vedat & 9 & Pertev Naili Boratav & 8 \\
Habib-i Neccar Camii & 10 & nallıhan & 9 & Sultan abdülaziz & 8 \\
hacet & 10 & tanzimat & 9 & Sultan II. Glyâseddîn & 8 \\
kök-türkler & 10 & tunca & 9 & Keyhüsrev & 8 \\
mahmud & 10 & yakutiye medresesi & 9 & & \\
Titus Tüneli & 10 & yörük & 9 & & \\
yağmu yağdırma Keykubad & & \\
& 10 & kurgan & 9 & & \\
\hline
\end{tabular}

Copyrights

Copyright for this article is retained by the author(s), with first publication rights granted to the Journal.

This is an open-access article distributed under the terms and conditions of the Creative Commons Attribution license (CC BY-NC-ND) (http://creativecommons.org/licenses/by-nc-nd/4.0/). 